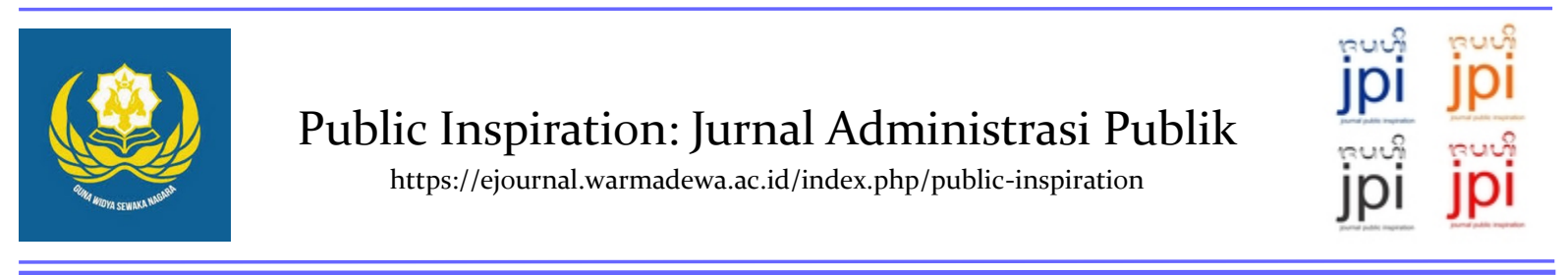

\title{
Sistem Mass Rapid Transit (MRT) DKI Jakarta: Studi Kasus Transfer Kebijakan Pendapatan Non-Farebox di Indonesia
}

\author{
Halifa Nurnadhifa* dan Hafizhah Nur Latifah \\ Universitas Indonesia, Depok, Jawa Barat \\ *Email Corespondence: halifa.nurnadhifa@ui.ac.id
}

How to Cite: Nurnadhifa, H., Latifah, H, N. (2021). Sistem Mass Rapid Transit (MRT) DKI Jakarta: Studi Kasus Transfer Kebijakan Pendapatan Non-Farebox di Indonesia. Public Inspiration: Jurnal Administrasi Publik, 6 (2): 97-106. DOI: https://doi.org/10.22225/pi.6.2.2021.97-106

\begin{abstract}
Policy transfer is the process of borrowing policies from other countries that have successfully implemented the idea in their home country. There are at least four things that need to be known in policy transfer, namely the form, the learning process, the obstacles in it, and errors in policy transfer. This paper will further examine the transfer of the Jakarta MRT policy in terms of the three aspects and see how far the policy transfer has been implemented. With descriptive qualitative research methods, the results of the study show that the transfer of the Jakarta MRT policy itself has been carried out well, although there are still some obstacles and errors in the policy learning process. For this reason, several corrections must be made to make the policy develop.
\end{abstract}

Keywords: MRT; policy transfer; non-farebox revenue

\begin{abstract}
Abstrak
Transfer kebijakan merupakan proses peminjaman kebijakan dari negara lain yang telah berhasil mengimplementasikan gagasan tersebut di negara asalnya. Setidaknya terdapat empat hal yang perlu diketahui dalam transfer kebijakan, yaitu bentuk, proses pembelajaran, hambatan di dalamnya, serta kesalahan dalam transfer kebijakan. Tulisan ini akan membedah lebih lanjut mengenai transfer kebijakan MRT Jakarta ditinjau dari ketiga aspek serta melihat sejauh mana transfer kebijakan tersebut telah dilaksanakan. Dengan metode penelitian kualitatif deskriptif, hasil penelitian menunjukan bahwa transfer kebijakan MRT Jakarta sendiri sudah terlaksana dengan baik, meskipun pada pelaksanaannya masih terdapat beberapa hambatan dan kesalahan dalam proses pembelajaran kebijakan. Untuk itu, diperlukan beberapa koreksi yang harus dilakukan untuk membuat kebijakan tersebut berkembang.
\end{abstract}

Kata Kunci: MRT; transfer kebijakan; pendapatan non-tiket.

\section{Pendahuluan}

DKI Jakarta merupakan Ibu Kota Negara yang menjadi pusat wilayah dan tergabung dalam suatu wilayah metropolitan berskala besar bersama dengan tujuh pemerintahan daerah di sekitarnya yaitu Bogor, Depok, Tangerang, dan Bekasi (Bodetabek) sebagai daerah penyangganya (Rahmadana, 2014). DKI Jakarta dan wilayah penyangganya menjadi daerah dengan satu kesatuan secara ekonomi yang memiliki ketergantungan antara satu sama lain yang teraglomerasi dalam wilayah yang dinamai Jabodetabek. Wilayah Jabodetabek termasuk kedalam wilayah urban dan suburban yang seringkali dipenuhi masyarakat bermobilitas tinggi (Sembiring, 2021). Jika ditilik lebih lanjut, masyarakat yang bermukim di wilayah Bodetabek seringkali menggantungkan hidupnya pada wilayah ibu kota dengan bermigrasi untuk bekerja di DKI Jakarta, begitupun sebaliknya, tidak sedikit pula masyarakat DKI Jakarta yang beraktivitas di daerah-daerah tersebut (Wiryono, 2021a). Orang-orang yang bermigrasi tetapi tidak menetap inilah yang kemudian disebut sebagai komuter atau sirkuler 
bagi sebagian orang (Rahmadana, 2014).

Para komuter berperan aktif dalam meningkatkan tingkat mobilitas masyarakat (Wiryono, 2021b). Jika melihat perilaku komuter Bodetabek, setidaknya terdapat perbedaan jumlah penduduk di DKI Jakarta pada siang hari dengan jumlah penduduk keseluruhan DKI Jakarta, di mana pada siang hari ada sedikitnya 14.5 juta warga yang beraktivitas di DKI Jakarta, sedangkan data keseluruhan menunjukkan jumlah penduduk DKI Jakarta sendiri mencapai 10.2 juta jiwa (LIPI, 2019). Sehingga dapat dikatakan bahwa setiap harinya para komuter Bodetabek menunjukan angka mobilitas yang tinggi terjadi di DKI Jakarta.

Dengan alasan yang beragam, mobilitas yang tinggi juga kerap kali menimbulkan permasalahan baru bagi lingkungan, terutama bagi wilayah urban atau perkotaan. Mobilitas berulang yang dilakukan oleh para komuter sendiri menyebabkan masalah yang signifikan baik itu untuk fisik (spasial), maupun juga sosial dan lingkungan. Todd (2013) menyatakan bahwa di dalam aspek fisik, tingkat mobilitas masyarakat yang tinggi dapat menyebabkan keterlambatan dan kemacetan.

Pada tahun 2020, DKI Jakarta yang notabene merupakan titik sentral dari wilayah Jabodetabek, pernah menduduki namanya pada daftar 10 kota termacet di dunia (TomTom, 2020). Apabila kemacetan tersebut berada di titik kulminasi, maka hal tersebut akan membawa kerugian bagi kota dan subwilayahnya. Kemacetan yang tidak dapat dihindarkan, dapat mengakibatkan adanya dorongan dari pesatnya pertumbuhan ekonomi yang terjadi di beberapa tahun belakangan, sehingga memicu terjadinya peningkatan konsumsi masyarakat akan kendaraan bermotor. Fenomena ini tentu menimbulkan kekhawatiran akan aktivitas ekonomi yang berakibat pada stagnasi distribusi barang dan jasa serta pertumbuhan ekonomi itu sendiri. Selain itu, pembuangan gas hasil pembakaran kendaraan bermotor juga dapat menimbulkan $80 \%$ polusi udara (PT MRT Jakarta, 2015). Hal ini berarti, kemacetan yang terjadi dapat menimbulkan kerugian yang cukup besar sebagaimana terakumulasi dari beberapa aspek seperti waktu, bahan bakar, dan kesehatan (PT MRT Jakarta, 2015).

Tingginya tingkat kemacetan yang terjadi harus segera dikurangi, sebab berkurangnya tingkat kemacetan memegang peranan penting bagi negara, di mana hal ini akan mendukung tercapainya target dan strategi pembangunan nasional. Mengingat pentingnya hal tersebut, pemerintah pada akhirnya berupaya untuk mendorong peningkatan penggunaan transportasi publik sebagai salah satu sarana yang dinilai mampu mengurangi kemacetan. Selain itu, hal ini juga selaras dengan peran transportasi publik yang dijelaskan oleh Sambuaga (2017), di mana transportasi publik disebut menjadi bagian penting dalam ranah perkotaan, yang tentunya memiliki signifikansi sama penting. Adapun, transportasi publik juga dibutuhkan mengingat pentingnya pemenuhan kebutuhan masyarakat itu sendiri, di mana diketahui penduduk Jabodetabek memiliki tingkat mobilitas yang sangat tinggi dan mobilitas crowded.

Pemerintah DKI Jakarta, setidaknya telah mengeluarkan banyak opsi transportasi publik, seperti Bus TransDKI Jakarta ataupun Kereta Commuter Line. Bahkan, belakangan ini pemerintah daerah, pusat, serta stakeholder lain berkolaborasi dalam rangka perwujudan salah satu transportasi publik yang tengah menjadi sorotan yakni kehadiran Mass Rapid Transit (MRT) bagi masyarakat. Di mana peningkatan kuantitas dan kualitas transportasi massal tersebut dilakukan dalam rangka pengalihan atensi masyarakat dari transportasi pribadi menjadi transportasi publik. tersebut hampir berlangsung setiap harinya.

Dalam proses pengembangannya, MRT sendiri hadir dengan cara yang dapat dikatakan cukup kontroversial. Hal ini bukan tanpa alasan, mengingat pemerintah sendiri perlu menghabiskan dana senilai 16 triliun untuk memastikan proyek tersebut selesai sesuai dengan timeline yang sudah direncanakan (Pramesti, 2019). Namun, di lain sisi proyek ini tetap harus dijalankan, mengingat keberadaannya dapat menjadi cerminan kemampuan DKI Jakarta dalam merumuskan strategi tata kota yang terpadu. Lebih lagi, DKI Jakarta sendiri sering dielukan sebagai parameter bagi kota-kota besar lain di Indonesia. 
Pembangunan yang memakan biaya cukup besar, sementara PT MRT tidak bisa hanya mengandalkan pendapatan yang bersumber dari biaya perjalanan yang ditetapkan, membuat PT MRT Jakarta beserta stakeholder bergegas mencanangkan skema kebijakan terbarukan (Rosana, 2019). Beberapa kandidat kebijakan tersebut terus bermunculan, hingga menyisakan beberapa desain kebijakan yang telah banyak diterapkan di negara-negara maju dan memberi dampak signifikan bagi pembangunan seperti model Transit on Demand, Nonfarebox revenue, dan pengintegrasian transportasi Jakarta (Anatasia, 2019).

Pembangunan MRT juga melalui perjalanan yang cukup panjang. Hal ini terbukti dari pelaksanaan proyek yang baru resmi berjalan setelah lebih dari 25 tahun proyek ini direncanakan, tepatnya pada 10 Oktober 2013 yakni ditandai dengan dilakukannya Project Groundbreaking oleh PT MRT Jakarta (PT MRT Jakarta, 2015). Pembangunan MRT dinyatakan sebagai mega proyek yang dapat menghubungkan titik-titik strategis di DKI Jakarta, di mana pembangunan ini ditetapkan menjadi prioritas kerja Pemerintah Provinsi DKI Jakarta sejak terpilihnya Joko Widodo sebagai Gubernur DKI Jakarta pada tahun 2012. Berbagai percepatan persiapan dilakukan, termasuk perubahan atas berbagai regulasi seperti Perubahan atas Perda Nomor 3 Tahun 2008 tentang Pembentukan Badan Usaha Milik Daerah (BUMD) PT MRT Jakarta dan Perubahan atas Perda Nomor 4 Tahun 2008 tentang Penyertaan Modal Daerah pada PT MRT.

Salah satu hal yang menarik dari proyek pembangunan MRT ini terletak pada kerja sama yang melibatkan pihak-pihak luar, yakni pemerintah Jepang melalui salah satu kontraktor besar negara tersebut di fase pertama pembangunan, yaitu Japan International Cooperation Agency (JICA) (Ramli, 2019). Kerja sama dilakukan dengan cara peminjaman dana dari JICA ke PT MRT, di mana pengambilan keputusan sendiri dilakukan oleh pihak JICA, sementara peran pembangunan, tata kelola, serta pengoperasian MRT kedepannya akan diampu oleh BUMD besutan provinsi DKI Jakarta (Listifadah, 2014). Secara tidak langsung, keterlibatan JICA dalam proyek MRT memberi pengaruh dalam penentuan kebijakan pembangunan. Singkatnya, kebijakan MRT Jakarta sendiri banyak ter-influenced dari kebijakankebijakan MRT yang ada di Jepang. Sebagaimana sudah menjadi rahasia publik, bahwa Jepang sendiri merupakan salah negara yang menjadi best practice dalam pemutakhiran MRT.

Selain Jepang, Singapura termasuk negara yang memberi dampak signifikan dalam pembangunan MRT Jakarta. Sebab, terdapat beberapa kebijakan yang terinspirasi dari penerapan MRT di negara singa tersebut. Di antaranya kebijakan non-farebox revenue atau non -tiket yang berfokus pada konektivitas dan menjadi keunggulan dari transportasi negara tersebut (Haryanto, n.d.). Di mana, Credo dalam Siemens Press (2014) juga menerangkan bahwa konektivitas mampu membawa Singapura menjadi negara dengan sistem transportasi paling efektif di dunia.

Jika ditilik lebih lanjut, kedua negara yang menjadi role model Indonesia dalam menjalankan proyek ini pun sama-sama memakai kebijakan non-farebox revenue sebagai penyokong pendapatan MRT-nya. Bahkan tidak tanggung-tanggung, 60\% pendapatan MRT Jepang sendiri berasal dari pendapatan non-tiketnya (Widyanto, 2018). Bahkan di tahun 2019, PT MRT Jakarta dengan resmi menyebutkan bahwa mereka akan membuat kebijakan yang sama untuk MRT Jakarta. Berangkat dari hal tersebut, penelitian ini bertujuan untuk mengetahui lebih jauh bagaimana transfer kebijakan tersebut berlaku di MRT Jakarta dan ingin mengomparasikan sejauh mana kebijakan tersebut jika dielaborasikan dibandingkan dengan negara yang model Indonesia tersebut.

\section{Konsep}

\section{Pengertian Transfer Kebijakan}

Apa yang dilakukan oleh PT MRT Jakarta terhadap tata kelola MRT Jepang dan Singapura disebut sebagai transfer kebijakan. Evans (2009) menjelaskan bahwa transfer kebijakan sendiri merupakan upaya penyebaran kebijakan atau beberapa aspek di dalamnya ke 
dalam satu unit pemerintahan atau lebih. Setidaknya ada empat aspek yang perlu diketahui mengenai transfer kebijakan, di antaranya bentuk dari transfer kebijakan, proses pembelajaran kebijakan, hambatan dalam prosesnya, serta kesalahan dalam transfer kebijakan (Evans, 2009). Transfer kebijakan juga sering diartikan sebagai "difusi kebijakan" yang lebih luas, di mana difusi memiliki makna penyebaran kebijakan di seluruh unit pemerintah terlepas dari apakah penyebaran itu berasal dari pengetahuan atau dari faktor lain seperti konvergensi - unit pemerintah mengadopsi kebijakan yang serupa dengan unit lain akibat masalah serupa. Adapun terminologi lain yang cukup mirip namun berbeda, yaitu bandwagoning (Ikenberry, 2019), emulasi (Howlett, 2000), dan lesson-drawing (Rose, 2004). Namun dapat dipastikan, bahwa transfer kebijakan adalah studi yang berakar dari teori difusi, di mana transfer kebijakan berfokus pada proses pembelajaran kebijakan yang ada di negara-negara berkembang, sedangkan difusi terbatas pada tren yang tinggal dan menetap antara negara maju yang satu dengan lainnya (Dolowitz \& Marsh, 2000).

\section{Bentuk Transfer Kebijakan}

Dalam transfer kebijakan, dikenal tiga bentuk proses transfer, yaitu transfer kebijakan yang prosesnya dilakukan sukarela, transfer kebijakan yang dinegosiasikan, dan terakhir transfer secara langsung dan memaksa (Evans, 2009). Transfer sukarela merupakan proses pembelajaran kebijakan yang dinilai paling rasional, di mana di dalamnya terdapat evaluasi dari negara peminjam kebijakan, mengenai apakah transfer kebijakan tersebut akan berlanjut untuk disalin, dimodifikasi, atau dibatalkan (Mossberger \& Wolman, 2003).

Bentuk transfer kebijakan yang kedua dan ketiga dinilai cukup ekstrem, karena terdapat unsur pemaksaan di dalamnya. Untuk bentuk transfer kebijakan yang dinegosiasikan, negara atau pemerintah biasanya akan dipaksa oleh pihak luar, baik itu negara kreditur, lembaga pinjaman internasional, atau lembaga berpengaruh lainnya untuk mengadopsi serta memperkenalkan suatu kebijakan yang ditentukan demi sebuah hibah, pinjaman, atau investasi lainnya (Ikenberry, 2019). Dengan bentuk transfer yang satu ini, politik internasional sangat berpengaruh di dalamnya, sehingga menimbulkan beberapa perjanjian-perjanjian di dalam proses kebijakan.

Bentuk transfer kebijakan yang terakhir adalah transfer secara langsung dan koersif. Di dalam bentuk ini, pemerintah secara paksa diperintah oleh negara lain untuk memperkenalkan kebijakan atau ideologi yang bertentangan dengan kemauan masyarakatnya (Wincott 1999, dalam Evans 2009). Bentuk transfer kebijakan yang satu ini sangatlah ekstrem karena memuat unsur imperialisme atau penjajahan modern.

\section{Proses pembelajaran berbasis kebijakan}

Evans (2009) membagi proses pembelajaran ke dalam empat proses yang berbeda, di mana setiap proses memiliki karakteristik yang sangat berbeda dan mudah dibedakan. Pertama ada proses penyalinan kebijakan tanpa adanya modifikasi sama sekali. Tipe yang satu ini sangat jarang sekali digunakan karena umumnya setiap negara atau unit pemerintah memiliki ciri khas yang berbeda satu dan lainnya. Proses pembelajaran yang kedua adalah emulasi, di mana pemerintah mencontoh desain kebijakan yang terbaik di bidangnya dari negara luar (contoh: Bogota dengan BRT-nya) (Howlett, 2000). Ketiga yaitu Hybridization, yang mana pemerintah mengombinasikan setting yang berbeda dalam melakukan transfer kebijakan (Evans 2004, dalam Evans 2009). Hal ini bukan tanpa alasan, melainkan untuk menyesuaikan kemampuan ataupun unsur-unsur budaya yang tidak sesuai. Jenis proses yang terakhir adalah inspirasi, di mana sebuah gagasan melatarbelakangi munculnya pemikiran baru mengenai permasalahan-permasalahan yang ada dan memfasilitasi perubahan kebijakan yang ada tersebut (Common, 2017).

\section{Metode}

Metodologi penelitian merupakan kumpulan teknik atau cara tertentu dalam penelitian yang dapat digunakan untuk menganalisis kehidupan sosial, mengumpulkan dan memper- 
baiki, menganalisa data dan juga melaporkan hasil penelitian (Neuman, 2014). Penelitian ini menggunakan pendekatan kualitatif dengan tipe penelitian deskriptif, yang menitikberatkan serta menjabarkan pemecahan masalah secara aktual. Adapun data yang digunakan dalam penelitian ini merupakan data sekunder, dengan teknik pengumpulan studi pustaka melalui studi penelaahan terhadap berbagai buku, literatur, dan laporan elektronik yang terkait MRT Jakarta.

\section{Hasil dan Pembahasan}

\section{Bentuk transfer kebijakan MRT Jakarta}

MRT Jakarta melakukan bentuk transfer kebijakan secara sukarela. Hal tersebut dikarenakan, pemerintah dan PT MRT Jakarta memiliki kebebasan secara penuh untuk memutuskan apakah akan memberlakukan kebijakan MRT baik Jepang maupun Singapura secara penuh, mengoreksi beberapa aspek, ataupun membatalkan pengadopsian kebijakan tersebut.

Dalam konteks PT MRT Jakarta melakukan transfer kebijakan atas hasil pembelajaran dari MRT Jepang yang dinilai mampu meraih kesuksesan pendapatan dalam memperoleh keuntungan melalui pendapatan non-tiket atau non-farebox (Parikesit, 2018). Pelayanan MRT Jakarta melakukan pengembangan sistem bisnis yang tidak hanya mengandalkan pendapatan atas penjualan tiket. Hal ini dilakukan MRT Jakarta dalam upaya menjaga pelayanan MRT Jakarta yang berkelanjutan dan berkesinambungan.

Penguatan pendapatan non-farebox dilaksanakan melalui pendayagunaan aset sistem operasi MRT Jakarta seperti pendapatan dari penyediaan media iklan, pengelolaan ritel dalam kawasan stasiun, serta pendapatan lain di luar pemanfaatan aset operasi, yaitu pendapatan properti dalam kawasan transit baik yang dimiliki maupun dikelola oleh perusahaan (PT MRT Jakarta, 2015). Melalui penguatan pendapatan non-farebox, pada tahun 2020 PT MRT Jakarta berhasil memperoleh realisasi pendapatan sebesar Rp 383 miliar yakni melebihi target yang telah ditetapkan yaitu sebesar Rp 321 miliar (PT MRT Jakarta, 2020).

Tingginya lalu lintas pengguna jasa MRT Jakarta juga dimanfaatkan PT MRT Jakarta sebagai sumber pendapatan berbasis jasa periklanan pada area stasiun MRT Jakarta dan layanan telekomunikasi. Hingga akhir tahun 2020 PT MRT Jakarta telah bekerja sama dengan Otego Media untuk melaksanakan pengelolaan 13 stasiun dan 16 rolling stock, serta Jakpro untuk melaksanakan pengelolaan viaduct dan pilar pada jalur layang (PT MRT Jakarta, 2020). PT MRT Jakarta memperkirakan, pengguna jasa MRT Jakarta pada tahun 2021 akan tumbuh signifikan sebesar $138 \%$ menjadi 65.000 orang per hari, dibanding tahun 2020 sehingga hal ini dapat dijadikan peluang untuk menambah daya tarik perusahaan-perusahaan untuk bermitra dengan PT MRT Jakarta (PT MRT Jakarta, 2020).

PT MRT Jakarta juga melakukan pelelangan untuk membuat kerja sama hak penamaan atau naming rights stasiun dengan perusahaan-perusahaan yang bermitra, di mana per akhir 2020, 5 dari 13 stasiun telah diberi nama sesuai dengan nama perusahaan yang bermitra. Perusahaan pemenang lelang membuat kontrak yang perlu diperpanjang dalam waktu satu atau lima tahun sesuai dengan kesepakatan pada awal pembuatan kontrak, disertai dengan pembayaran baru dari perusahaan pemenang lelang yang dibayarkan kepada PT MRT Jakarta (CNN Indonesia, 2019). Adapun lima perusahaan yang sudah mendapatkan kontrak hak penamaan stasiun, yakni PT Bank Negara Indonesia (Persero) Tbk pada Stasiun Dukuh Atas BNI, PT Astra International stasiun pada Stasiun Setiabudi Astra, PT Bank Mandiri (Persero) Tbk pada Stasiun Istora Mandiri, PT Bank Central Asia Tbk pada Stasiun Blok M BCA dan PT Grab Indonesia pada Stasiun Lebak Bulus Grab (Republika, 2019). Diperkirakan, PT MRT Jakarta akan membuka 5 stasiun lain untuk bermitra dengan perusahaan melalui hak penamaan.

Selanjutnya, PT MRT Jakarta juga membuka dan menyediakan area komersial atau terintegrasi dengan area komersial di luar area MRT Jakarta yang ditujukan bagi Usaha 
Mikro Kecil dan Menengah (UMKM) di sekitar area stasiun. Dibukanya area komersial memberikan dampak yang baik, karena selain mampu menyediakan layanan transportasi publik bagi masyarakat, hal tersebut juga mampu memberikan dampak sosial-ekonomi yang baik di kawasan sekitar stasiun MRT Jakarta. Melalui Peraturan Direksi No.PER/004/BODMRT/I/2019 tentang Pedoman Tata Laksana Seleksi Untuk Usaha Mikro Kecil Menengah (UMKM) sebagai Tenant Retail di Stasiun MRT Jakarta, PT MRT Jakarta meresmikan kebijakan tersebut, di mana di dalamnya juga mencakup mekanisme kerja sama dengan pelaku UMKM (PT MRT Jakarta, 2019).

Dalam upaya memberikan dukungan secara optimal kepada UMKM, PT MRT bekerja sama dengan Badan Ekonomi Kreatif (BEKRAF) melakukan proses kurasi dalam memilih 14 UMKM dari dari tiga kategori, yakni 7 UMKM di bidang kuliner, 4 UMKM di bidang fashion, dan 3 UMKM di bidang kriya (PT MRT Jakarta, 2020a). Di mana UMKM tersebut kemudian akan ditempatkan pada tiga stasiun MRT Jakarta yang memiliki angka laju pengguna jasa cukup strategis, yaitu pada Stasiun Lebak Bulus Grab, Stasiun Fatmawati, dan Stasiun Dukuh Atas BNI. Dari hasil seleksi yang telah dijalankan, 14 booth UMKM telah beroperasi, sehingga diharapkan dapat memberikan nilai tambah kepada stasiun MRT Jakarta dan menjadi identitas pada area sekitar stasiun MRT Jakarta (PT MRT Jakarta, 2019).

Peningkatan pengembangan pendapatan non-farebox merupakan adaptasi dari MRT Jakarta yang dilakukan atas hasil pembelajaran jurnalis yang memotret beberapa strategi bisnis pada stasiun di Jepang, seperti Stasiun Hakata City, Osaka, dan Shinjuku. Ketiga stasiun tersebut memiliki berbagai iklan yang memadati stasiun dalam bentuk papan iklan digital dengan berbagai ukuran yang dipajang pada dinding dan pembatas stasiun (Parikesit, 2018). Selain itu, mayoritas stasiun besar di Jepang juga dilengkapi dengan pusat belanja, restoran, toko kelontong, toko obat, hingga toko oleh-oleh, sehingga area stasiun menjadi area komersial yang tidak hanya dipadati oleh pengguna layanan jasa transportasi, melainkan pengunjung yang akan berbelanja.

\section{Proses Pembelajaran MRT Jakarta}

Dalam pelaksanaan proses pembelajaran, peneliti menyimpulkan bahwa jenis proses dalam transfer kebijakan ini disebut sebagai Hybridization, di mana transfer kebijakan yang dilakukan pemerintah tidak dilakukan secara total, namun mengurangi atau menambahkan beberapa ketentuan dengan memperhatikan budaya dan kebiasaan masyarakat yang sudah ada.

Proses pembelajaran yang dilakukan PT MRT Jakarta dapat dilihat melalui pelaksanaan kegiatan Journalist Fellowship Program I dan II yaitu pada bulan Januari dan Desember 2014. Program ini dilaksanakan dalam rangka meningkatkan pemahaman para insan media terhadap kompleksitas dari pembangunan MRT, sebagaimana pembangunan proyek MRT juga memerlukan dukungan dari media massa baik cetak maupun elektronik.

Journalist Fellowship Program I merupakan kunjungan dan studi ke LTA Singapore dan MYMRT Kuala Lumpur yang dilakukan oleh jurnalis terpilih beserta delegasi PT MRT Jakarta. Kunjungan dan studi yang dilakukan ke LTA Singapore diarahkan kepada pusat kota Singapura, sehingga para jurnalis mendapatkan informasi terkait LTA Gallery dan information Centre LTA. Sementara, para jurnalis juga mendapatkan pemahaman terkait bagaimana aktivitas dan konstruksi di MYMRT Kuala Lumpur dilaksanakan dan dikomunikasikan kepada publik, sebagaimana hal tersebut dapat diimplementasikan pada pembangunan proyek MRT Jakarta khususnya dalam bentuk komunikasi kepada masyarakat mengenai kegiatan konstruksi yang dilakukan. Lokasi yang dijadikan sebagai referensi aktivitas komunikasi pengerjaan proyek dianggap memiliki karakteristik yang sama dan dapat mewakili kondisi pembangunan MRT Jakarta pembangunan proyek MRT Jakarta, sebagaimana wilayah tersebut merupakan stasiun underground yang terletak pada area urban yang cukup padat dan kompleks di area Kuala Lumpur. 
Sedangkan pada Journalist Fellowship Program II merupakan kunjungan studi ke Tokyo Metro dan JR West di Tokyo dan Osaka, Jepang. Dalam program tersebut, para peserta difokuskan kepada pendalaman informasi terkait dukungan media dalam skema pengembangan dan peranannya sebagai tulang punggung bisnis bagi Tokyo Metro, sebagaimana hal ini dapat diterapkan dalam peranan dan bisnis utama PT MRT Jakarta. Selain itu, peserta juga mendapatkan informasi penerapan metode Transit Oriented Development (TOD) yang dilakukan Shibuya Redevelopment Project sebagaimana hal ini sangat sesuai untuk dijadikan pembelajaran bagi MRT Jakarta. Selain itu, peserta juga mengunjungi Ministry of Land Infrastructure and Tourism (MLIT) untuk mempelajari kondisi bisnis perkeretaapian serta strategi bisnis pengembangan komersial pada area sekitar stasiun di Jepang.

\section{Hambatan dalam pembelajaran}

Setelah beberapa tahun MRT Jakarta beserta dengan kebijakannya diimplementasikan di Indonesia, kebijakan non-farebox atau non-tiket menimbulkan dampak yang berbagai macam dalam perkembangannya. Tentunya dampak tersebut tidak selalu berupa dampak positif, sehingga dalam proses transfer kebijakan masih memerlukan adanya koreksi. Tetapi, sulit memungkiri bahwa proses pembelajaran kebijakan tersebut juga banyak menemui hambatan. Kerikil hambatan yang dimaksud, yaitu terletak pada kondisi negara penggagas dan juga peminjam kebijakan yang berbeda.

Dalam hal ini, kedua negara penggagas kebijakan non-farebox, yaitu Jepang dan Singapura merupakan negara-negara yang maju dan tentunya memiliki rentang pendapatan serta pengalaman yang tinggi. Untuk Singapura sendiri, tarif periklanan terbilang cukup terjangkau untuk masyarakat ataupun organisasi yang ingin mempromosikan sesuatu, lebih lagi pengelolaannya dilakukan bersama-sama dengan agensi periklanan swasta ternama layaknya Stellar Ace dan juga Moove Media (Stellar Ace, n.d.).

Berbeda dengan negara-negara tersebut, pihak MRT Jakarta sendiri nampaknya cukup kesulitan untuk mencari pengiklan dan partner yang mau menyewa ruang stasiun ataupun MRT demi keperluan komersil. Itu karena proyek MRT sendiri selesai berdekatan pada saat pandemi virus Covid-19 melanda di wilayah Indonesia, sehingga banyak perusahaan berpikir dua kali untuk mengalokasikan dananya demi keperluan periklanan (Rahardyan, 2020). Namun dengan kondisi yang seperti itu, MRT Jakarta tetap mampu menggandeng namanama besar, seperti PT Bank Negara Indonesia Tbk dan juga PT Grab Indonesia untuk mau bergabung ke dalam proyek naming rights yang masuk ke dalam kebijakan non-farebox revenue (Pebrianto, 2019).

\section{Kesalahan dalam pembelajaran}

Walaupun transfer kebijakan terlihat seperti tanpa cela dari luar, nyatanya terdapat beberapa kesalahan yang mengakibatkan ketidaksempurnaan pada implementasinya. Adapun kesalahan yang dimaksud peneliti yaitu terletak pada sistem akuntabilitas pemasaran PT MRT Jakarta. Seperti yang diketahui sebelumnya, salah satu kunci dari keberhasilan kebijakan non-farebox adalah kemampuan organisasi untuk memasarkan barang dan jasanya. Namun, yang terlihat saat ini, pemasaran jasa oleh MRT tidak seterbuka Singapura maupun Jepang. Hal ini terlihat dari website MRT Jakarta yang menawarkan jasa secara tertutup, di mana hanya tertera kontak dari pihak pemasaran tanpa ada info lebih lanjut. Berbeda dari itu, agensi periklanan Singapura dan Jepang yang menawarkan space MRT bagi para pengiklan benar-benar memberi informasi terperinci mengenai jenis layanan, durasi, sampai dengan harga, yang mana membuat para pengiklan dapat memperoleh informasi dalam sekali klik. Sistem keterbukaan teknologi informasi dalam pemasaran ini juga sempat disinggung oleh Setiawan dan Akbarini (2016), yang berpendapat bahwa keterbukaan informasi tersebut sangat penting dalam pengoptimalan kualitas layanan.

\section{Kesimpulan}

Pada dasarnya, transfer kebijakan adalah hal yang lumrah dilakukan oleh negara di 
belahan dunia manapun. Bahkan, transfer kebijakan sendiri dapat meminimalisasi kegagalan karena kebijakan yang ada umumnya sudah berhasil diterapkan oleh negara penggagas kebijakan tersebut. Namun, transfer kebijakan juga dapat menghasilkan efek yang negatif apabila prosesnya tidak dilakukan dengan layak atau sesuai.

Jika berbicara mengenai transfer kebijakan non-farebox yang diampu oleh MRT Jakarta, pelaksanaannya sendiri telah mengarah ke arah yang positif dan pihak pengelola pun telah berupaya sekeras mungkin untuk menyesuaikan elemen yang dahulunya sukses diterapkan di Singapura dan Jepang dapat bekerja dengan cara yang sama di Jakarta. Namun, tidak dapat disangkal bahwa masih ada kerikil-kerikil kecil yang menghambat keberlangsungan kebijakan tersebut, seperti kondisi kedua negara yang berbeda.

Agar kebijakan non-farebox dapat terus diberlakukan dan memberikan hasil yang optimal, maka diperlukan koreksi yang dapat membuat kebijakan tersebut berkembang. Bentuk koreksi yang dimaksud ialah keterbukaan informasi pemasaran dalam pendapatan nontiket. Hal ini bisa dilakukan oleh PT MRT Jakarta sendiri dengan cara mencantumkan informasi layanan periklanan melalui website-nya atau dapat juga dilakukan bersama dengan stakeholder luar seperti agensi-agensi periklanan yang sudah mumpuni.

\section{Daftar Pustaka}

Anatasia, R. (2019, March 15). 4 Kebijakan Lanjutan untuk Optimalkan Layanan MRT Jakarta. Tribun. Retrieved November 27, 2021, from https://www.tribunnews.com/bisnis/2019/03/15/4 -kebijakan-lanjutan-untuk-optimalkan-layanan-mrt-jakarta

CNN Indonesia. (2019, April 11). MRT Jakarta Raih Pendapatan Besar dari Hak Penamaan Stasiun. CNN Indonesia. Retrieved November 24, 2021, from https://www.cnnindonesia.com/ ekonomi/20190411114235-92-385282/mrt-jakarta-raih-pendapatan-besar-dari-hak-penamaanstasiun

Common, R. (2017). Public management and policy transfer in South-East Asia (pp. 143-161). Routledge.

Dolowitz, D. P., \& Marsh, D. (2000). Learning from abroad: The role of policy transfer in contemporary policy $\square$ making. Governance, 13(1), 5-23.

Evans, M. (2009). Policy transfer in critical perspective. Policy studies, 30(3), 243-268.

Haryanto, W. (2019, April 29). JPI - Bisakah MRT Jakarta Lebih Unggul dari Singapura? Jakarta Property Institute. Retrieved November 27, 2021, from https://www.jpi.or.id/blog/2019/04/29/ bisakah-mrt-jakarta-lebih-unggul-dari-singapura

Howlett, M. (2000). Beyond legalism? Policy ideas, implementation styles and emulation-based convergence in Canadian and US environmental policy. Journal of public policy, 20(3), 305-329.

Ikenberry, G. J. (2019). The International Spread of Privatization Policies: Inducements, Learning, and" Policy Bandwagoning". In The political economy of public sector reform and privatization (pp. 88-110). Routledge.

LIPI. (2019). Mobilitas Sirkuler Jabodetabek. http://lipi.go.id/publikasi/mobilitassirkulerjabodetabek/27075

Listifadah, L. (2014). Dampak Sosial Proyek Kereta Api Studi Kasus Mass Rapid Transit (MRT) Jakarta, Indonesia. Warta Penelitian Perhubungan, 27(1), 19-28.

Mossberger, K., \& Wolman, H. (2003). Policy Transfer as a Form of Perspective Policy Evaluation: Challenges and Recommendations. Public Administration Review, 63(4), 428-440.

Neuman, W. (2014). Social research methods: Qualitative and quantitative approaches.

Parikesit, G. (2018, December 3). MRT Jakarta Tiru Jepang, Genjot Pendapatan Non-Tiket. Tempo.co. Retrieved November 27, 2021, from https://metro.tempo.co/read/1151759/mrt-jakarta- 
tiru-jepang-genjot-pendapatan-non-tiket

Pebrianto, F. (2019, March 29). Empat Perusahaan Dapat Hak Nama Stasiun MRT. Tempo.co. Retrieved November 27, 2021, from https://bisnis.tempo.co/read/1190537/empat-perusahaandapat-hak-nama-stasiun-mrt

Pramesti, I. A. (2019, March 6). Sri Mulyani: Biaya MRT Rp 16 T, Tak Balik Modal Via Tiket. CNBC Indonesia. https://www.cnbcindonesia.com/news/20190306191422-4-59335/srimulyani-biaya-mrt-rp-16-t-tak-balik-modal-via-tiket

PT MRT Jakarta. (2015). Overcoming Challenges to Build the Mega Project (Laporan Tahunan 2014). MRT Jakarta. Retrieved November 27, 2021, from https://jakartamrt.co.id/sites/default/ files/2020-07/Annual-Report-MRT-Jakarta-2014.pdf

PT MRT Jakarta. (2019). TOGETHER WE CREATE MORE VALUE (LAPORAN TAHUNAN 2019 PT MRT JAKARTA (PERSERODA)). MRT Jakarta. Retrieved November 20, 2021, from https://jakartamrt.co.id/sites/default/files/2020-09/Annual-Report-MRT-Jakarta-2019.pdf

PT MRT Jakarta. (2020). GROWING IN SUSTAINABILITY (Laporan Keberlanjutan 2020 Sustainability Report). MRT Jakarta. Retrieved November 20, 2021, from https://jakartamrt.co.id/ sites/default/files/2021-08/MRT\%20SR2020_Esig\%20Dekom_290721.pdf

Rahardyan, A. (2020, April 29). MRT Jakarta Siapkan 4 Skenario Bertahan dari Pandemi Covid-19. Ekonomi Bisnis.com. Retrieved November 25, 2021, from https://ekonomi.bisnis.com/ $\mathrm{read} / 20200429 / 98 / 1234683 / \mathrm{mrt}$-jakarta-siapkan-4-skenario-bertahan-dari-pandemi-covid-19

Rahmadana, M. F. (2014). Karakteristik Komuter dan Kualitas Hidup. Jurnal Ekonomikawan, 14 (01), 1-8.

Ramli, R. (2020, January 10). JICA Siap Bantu Pemerintah Danai Proyek MRT di Beberapa Kota. Money Kompas.com. Retrieved November 27, 2021, from https://money.kompas.com/

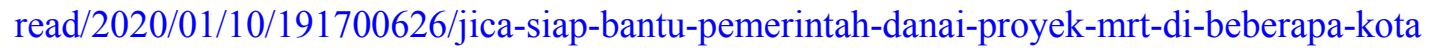

Republika. (2019, November 28). MRT Jakarta Tawarkan Lima Hak Penamaan Stasiun. Republika. Retrieved November 24, 2021, from https://republika.co.id/berita/q1nl1k383/mrt-jakartatawarkan-lima-hak-penamaan-stasiun

Rosana, F. C. (2019, March 7). Sri Mulyani Jelaskan Sebab MRT Tak Mungkin Untung dari Jual Tiket. Bisnis Tempo.co. https://bisnis.tempo.co/read/1182676/sri-mulyani-jelaskan-sebab-mrttak-mungkin-untung-dari-jual-tiket

Rose, R. (2004). Learning from comparative public policy: A practical guide. Routledge.

Sambuaga, R. (2017). Manajemen Penanggulangan Kemacetan Transportasi Publik Di Dinas Perhubungan Kota Manado. Jurnal Ilmiah Society, 1(24), 4.

Sembiring, L. J. (2021, April 11). Cek Guys! Daftar Wilayah Bisa Mudik, Ada Jakarta sampai Medan. CNBC Indonesia. Retrieved November 25, 2021, from https://www.cnbcindonesia.com/ news/20210411131129-4-236918/cek-guys-daftar-wilayah-bisa-mudik-ada-jakarta-sampaimedan

Setiawan, A., \& Akbarini, N. R. (2016). PEMBERDAYAAN ERA KETERBUKAAN TEKNOLOGI INFORMASI UNTUK MEMPERMUDAH PEMASARAN PRODUK MELALUI ECOMMERCE. In Prosiding Seminar Pendidikan Ekonomi dan Bisnis (Vol. 2, No. 1).

Siemens Press. (2014, June 2). Study: Singapore has one of the world's most efficient transportation. SIEMENS. Retrieved November 27, 2021, from https://press.siemens.com/sg/en/pressrelease/ study-singapore-has-one-worlds-most-efficient-transportation-systems

Stellar Ace. (n.d.). Leading Out-of-Home Media Owner - For Effective Outdoor Advertising. Stellar Ace. Retrieved November 27, 2021, from https://www.smrtmedia.com.sg/Who-We-Are

Todd, L., 2013. Smarter Congestion Relief in Asian Cities, UNESCAP: Transport and Communica- 
tions Bulletion for Asia and the Pacific.

TomTom. (n.d.). DKI Jakarta, Kota Termacet 10 Dunia. databoks. https://databoks.katadata.co.id/ datapublish/2020/02/20/dki-jakarta-kota-termacet-10-dunia

Widyanto, U. (2018, December 2). MRT Jakarta Tiru Jepang, Genjot Pendapatan Non-Tiket | Tempo.co. LINE TODAY. Retrieved November 27, 2021, from https://today.line.me/id/v2/article/ L2VJVG

Wiryono, S. (2021a, May 7). Kasatpol PP DKI: Berangkat Kerja dari Bodetabek ke Jakarta Harus Ada Surat Tugas Kantor Halaman all - Kompas.com. Megapolitan Kompas.com. Retrieved November 25, 2021, from https://megapolitan.kompas.com/read/2021/05/07/14080621/ kasatpol-pp-dki-berangkat-kerja-dari-bodetabek-ke-jakarta-harus-ada-surat?page=all

Wiryono, S. (2021b, April 19). Data IQAIR Senin, Kualitas Udara Jakarta Terburuk Keempat di Dunia. Kompas. 